\title{
Is Europe Still Worth Fighting For? Allegiance, Identity, and Integration Paradigms Revisited 1
}

Pablo Cristóbal Jiménez Lobeira²

Abstract: The paper reviews the foundational ideals that gave "Europe", an integration project with continental ambitions, its initial meaning or identity. "Europe" meant reconciliation and peace, reconstruction and widespread prosperity, and the mitigation of nationalism through the creation of supranational communities. A broad cultural consensus made it easier to trust each other and work together. The enterprise received a tacit approval from Europeans throughout the initial stages. More than 60 years and 20 member states later the project is under strain in the social, economic, political and cultural fields. Today, as Europeans (now continental citizens) experience not only the advantages, but also the sacrifices of belonging to "Europe" (in the form of a Union), their allegiance to, and indeed the identity of the whole project are in question. I will submit that the original identity of "Europe" should be revived, and revisited for it to evolve in response to the present challenges. If its future identity is that of an intercultural, inclusive, flexible, and analogical polity, Europe will be still worth fighting for.

Keywords: allegiance, analogical unity, European citizens, European foundational ideals, flexible integration, inclusive public sphere, interculturalism, political identity

Allegiance to "Europe" is more problematic than, say, commitment to a nation state, due to the nature of the European polity. The EU cannot claim to possess attributes that provoke strong (or at least significant) identification from its citizens. ${ }^{3}$ This is why the legal figure of European citizenship-especially when one focuses on the affiliative ${ }^{4}$ dimension of citizenship-presents a most interesting case in the study of the interactions between international and public law, between domestic and transnational identities, and between allegiance to nation and to community of nations.

In this paper I will explore the ideals of the European project that received a tacit allegiance from Europeans at the foundational stages. In 
the second section, I will mention some of the problems that the project faces at the present, which have put in jeopardy the identity of "Europe" (the EU today) and demand a more explicit allegiance from the now European citizens, at a moment when that allegiance is wavering. In the final part, I will suggest that a revival of the foundational ideals, revisited according to the new challenges, could give Europe a renewed identity, worth its citizens paying allegiance to.

\section{Original integration paradigms}

According to Joseph Weiler, the European Communities (which would evolve into the EU) were created with three goals in mind: social integration (reconciliation and peaceful coexistence); economic integration (reconstruction and widespread prosperity); and political integration (restraint of nationalism through supranational structures). ${ }^{5}$ These elements constituted the purpose or telos of integration, as can be seen in the Schuman Declaration. ${ }^{6}$

Prosperity, the moderation of nationalism, and peace were, in Weiler's view, objectives with more than a purely utilitarian intent. They were ideals: a set of values, which could captivate the imagination of Europeans, mobilise broadly based political forces, and counteract the powerful pull of nationalism. ${ }^{7}$ Those ideals represented not just any values, but "higher" ones: desiderata that were altruistic (not self-serving, but implying a sacrifice), ethical (virtuous) and communitarian (needing the cooperation of all).

Underlying those three ideals or goals was a broad moral consensus springing from shared-or at least to a certain extent compatibleworldviews. ${ }^{8}$ Because that cultural atmosphere was obvious to most, it required little discussion or specification: it simply was assumed. At the heart of such European culture of the 1950s were the religious tradition of the Bible (Judeo-Christianity) ${ }^{9}$ and the secular tradition of the Enlightenment. ${ }^{10}$ These four characteristics appear as features qualifying the foundational high values or ideals in Table 1. ${ }^{11}$

Table 1 - Original ideals and their features

\begin{tabular}{|l|l|l|l|l|}
\hline $\begin{array}{l}\text { Feature } \\
\text { Ideal }\end{array}$ & Desideratum & Altruistic & Ethical & Communitarian \\
\hline Social & Peace & Reconciliation & Forgiveness & Coexistence \\
\hline Economic & Prosperity & Equality & Solidarity & Common market \\
\hline Political & Unity & Supranationalism & Moderation & Co-sovereignty \\
\hline Culture & \multicolumn{3}{|c|}{ Basic moral consensus Bible/Enlightenment } \\
\hline
\end{tabular}




\section{The social ideal: security and pax europaea}

After a conflagration like the Second World War, the goal of peace could have hardly surprised anyone. It was obvious that nobody wanted another event like that. Europe could not afford it. However, Weiler believes that the kind of peace that the founders of the European project had in mind was more than a purely utilitarian goal: it possessed the features of an ideal. It was a call not only to stop the violence, but also to forgive and to overcome hatred. "The Schuman notion of peace" in Weiler's view, "resonates with and is evocative of the distinct discourse, imagery and values of Christian love", which was natural in that historical context and given the personal backgrounds of such founding fathers as Adenauer, De Gasperi, Monnet and Schuman himself. ${ }^{12}$

Peace certainly was a desideratum. However, it contained as well an altruistic element, an implied sacrifice beyond the appeasement mood of the 1930s. It required therefore the exercise of virtues: for example overcoming the desire for revenge and for the humiliation of the former enemy. It was, finally, only attainable through an effort involving the community of European nations-France and Germany first, then the Six, and so on. ${ }^{13}$

\section{The European economic ideal}

For Weiler the economic reconstruction of the devastated continent was "intimately connected with the notion of peace."14 Here the search for prosperity contained an altruistic element, because prosperity was a condition for peace. But mediating the utilitarian aspects of prosperity was an idealistic, virtuous element, evident when contrasted with the destruction and poverty of Europe in the aftermath of the Second World War: the element of individual and social dignity. Under the Enlightenment vision of the individual, "poverty resonates with the embarrassment of dependence on others, with the humiliation bred by helplessness, and with the degradation of a lack of autonomy". ${ }^{15}$

There was indeed virtue in the pursuit of prosperity as a means to promote the dignity of individuals, regions, nations, and Europeans as a whole. Prosperity won through hard work and effort, as well as through cooperation with other individuals and nations. The Community aimed at reconstruction with a sense of collective responsibility. It "attempted to constrain the unchecked search for economic prosperity by one Member State at the expense of the others". ${ }^{16}$ Thus, the processes of liberalisation of barriers and open markets to which the European project aspired were conceived, at the same time, in a context of solidarity. 


\section{The European political ideal}

Weiler has called the third ideal of European integration "supranationalism". ${ }^{17}$ Political integration can be envisaged either as a union or as a community. The community vision, on the one hand, affirms "the values of the liberal nation state by policing the boundaries against abuse". On the other hand it also "seeks to redefine the very notion of boundaries of the state, between the nation and the state and within the nation itself." 18 The unity vision is liberal and federal (and can be utilitarian as well); the community vision is communitarian and hybrid. ${ }^{19}$ The unity vision entails the end of supranationalism-that is, of checks on national-statisms-because it creates a super-state. ${ }^{20}$ The community vision advocates a stateless polity. ${ }^{21}$

Supranational cooperation was from the beginning a desideratum: it meant moderating the excesses of nationalism; or more precisely, those of states trying to advance their "national" interest in the European arena. It aimed at the creation of a transnational atmosphere where individual nation states became linked to other national or subnational groups across the European Communities, so that the main distinguishing category between peoples ceased to be their sense of belonging to a nation state. Supranationalism in this sense entails also an altruistic aim for Europeans to see each other in terms that go beyond the usual category of state- nationality. Weiler sees in this supranationalism an heir to the Enlightenment in its privileging of the value of every human individual, expressed for example in the liberal notion of human rights. ${ }^{22}$ In addition, as in the case of the ideals of peace and prosperity, supranationalism could not be attained by nation states separately: it required the assent and collaboration of all of them.

Even though the community vision dominated during the initial stages of European integration, the project has more and more tended towards a unity conception, especially after the Maastricht Treaty in 1993 (which created a the "European Union" and its citizenship), and even more with the attempt ten years later to draft a European Constitution (which failed). The EU today is far much more than an international organisation. But it seems to face decided resistance (both from member states and from citizens) in order to become a (super) state. ${ }^{23}$ Thence the appropriateness of remembering the community vision, and of revisiting it according to the new circumstances.

\section{Culture: the basic moral consensus}

The shared worldview or "basic moral consensus"24 that allowed Europeans to start the project of integration was based on two main 
cultural sources often in conflict but not altogether incompatible with each other: the Bible and the Enlightenment. ${ }^{25}$ Actually, because of their contrast, they served to keep a certain cultural balance in the European communities as they included more and more countries. The role of the Enlightenment or humanistic secularism is generally acknowledged as part of the make-up of Europe in general, and of the EU in particular, with roots that can be traced back to the French Revolution and the beginnings of Modernity. ${ }^{26}$ The role of Christianity, not only as a question of heritage from medieval history, but as a specific and essential force propelling European integration in the second half of the 20th century, seems to have been less studied. ${ }^{27}$

In this section, we have seen how the social, economic and political ideals of the European project were founded on core cultural values provided respectively by Judeo-Christianity and the Enlightenment. ${ }^{28}$ This is why, for Weiler, the project was successful both at the level of elites and at a broader societal level.

\section{Midlife crisis: challenges today}

Against the expectations of detractors, sceptics and critics, the project has been one of the greatest successes in the history of Europe. ${ }^{29}$ However, Europe today appears to be in a "midlife crisis". ${ }^{30}$ Probably it is natural that it should happen that way. After all, the EU now encompasses not two (or six) countries, but 27. ${ }^{31}$ Because of that, it faces new challenges. In the first part of the paper, I briefly described the original objectives and the ideals that set the European project in motion, gave it an identity, and made it successful. ${ }^{32}$ In this second part I describe the challenges that today make the integration process show some signs of exhaustion and the allegiance of European citizens waver.

\section{Parallel societies}

Social integration is being challenged by the presence of new immigrants and citizens of diverse cultural backgrounds. This is evident in the case of at least two minorities already present in the EU: the Roma and Muslims. For reasons of space I will mention recent situations related to the latter, though the former is no less important. ${ }^{33}$

In 2010 Thilo Sarrazin, then still a board member of the Bundesbank, published Deutschland schafft sich ab: wie wir unser Land aufs Spiel setzen (Germany does away with itself: how our country is putting itself at risk $)^{34}$, a book signaling to the lack of integration of Muslims in Germany (63\% of whom are Turkish). ${ }^{35}$ The publication attracted the attention not 
only of political or intellectual elites but also "a mass following from the population at large ${ }^{\prime \prime 36}$.

Other signs are the increased popularity of far-right parties with antiimmigration agendas in the Netherlands, ${ }^{37}$ Sweden, ${ }^{38}$ France, ${ }^{39}$ Denmark, Austria, Hungary and Italy; ${ }^{40}$ the debate about the ban on wearing the Islamic veil in public, particularly in France and Belgium, and on the construction of minarets in Swiss mosques. ${ }^{41}$ In the background of these debates stands the likely decrease in the whole of Europe's population in the near future, even after considering the effect of immigration. ${ }^{42}$

\section{Economic fragmentation}

The idea that a transnational currency may be able to survive without a state seemed plausible at least until the Greek crisis at the beginning of $2010 .{ }^{43}$ Since then, economic integration has faced the possibility of derailing, creating several blocks within an EU that run at different speeds. ${ }^{44}$

Risks to the euro's stability during the financial crisis have brought proposals by the EU Commission to regulate markets more closely, but also to tighten control over Member State's finances. ${ }^{45}$ Not everybody agrees with this step because it implies that nation state governments would have to give more sovereignty to Brussels. ${ }^{46}$ More importantly, many citizens have concerns about the euro's impact on their national economies. ${ }^{47}$ There are even fears that they are no longer well served by the single market and that the EU needs to revive the objective of the social market economy.48

Due largely to an impasse caused by a lack of leadership among the politicians who could make a difference (see next section), the eurozone's peripheral difficulties became problems, and after months of ineffective actions those problems evolved into a crisis that is threatening not only the common currency but the whole European project itself. The latest literature on the future of Europe seems everything but optimistic. ${ }^{49}$

\section{Political impasse}

Political integration is weakening under pressure from three forces that pull the EU in different ways. Euro-statists want the process to continue towards full union, the closest thing possible to a strong federal state that provides, they believe, a more definite and therefore stable situation..$^{50}$ They would fall under Weiler's "union vision" mentioned above. Intergovernmentalists push for devolution of as many competences as possible ceded in the past to Brussels. For them the process has already gone too far. Finally, advocates of a supranational but stateless polity, 
those who favour Weiler's "community vision", see the present situation of the political integration process not necessarily as an anomaly, but rather as the most desirable and workable state of affairs that needs only to be perfected..$^{51}$

All of them agree-and this is a widespread perception among EU citizens as well-that as a polity the EU lacks sufficient legitimacy. ${ }^{52}$ This "democratic deficit" is one of the most intricate present challenges in the political field.

\section{Cultural radicalisation}

As has been seen above, in parallel with traditions originating from the Enlightenment-including liberalism and social democracy-which share a secularist worldview, other influences have shaped contemporary Europe too. A very important one is Judeo-Christianity, and not only historically but also in the construction and evolution of European integration. The 2003 debate about whether to mention God and religion in the European constitution was not accidental, ${ }^{53}$ but revealed a latent challenge to the dominant cultural paradigm: ideological secularism..$^{54}$

According to Casanova, secularist ideology "positively [differentiates] modern secular Europeans from 'the religious other,' either from pre-modern religious Europeans or from contemporary non-European religious people". ${ }^{55}$ Secular ideological elites that see religion with suspicion and as a threat to the public sphere ${ }^{56}$ are likely to exacerbate the problem of the encounter with Islam, ${ }^{57}$ whose growing presence has to be factured in on the European cultural landscape.

The European enterprise, therefore, successful so far to a large extent, is undergoing strains in all three areas: social, economic and political. The cultural consensus at the foundation stages of the communities, allowed Europeans to obviate debate about ideals, and focus instead on practical issues. As Europe passes its 60, the situation has changed. There is no longer a clear cultural consensus. Ideals and paradigms for integration should be revisited if the European project is to survive.

\section{Reviving ideals, revisiting paradigms}

With Weiler, I would like to suggest that a renewed analysis of the ideals of integration could explain not only why the process was so successful in the past, but also what the constitutive elements, and the identity of the European project were. That might in turn shed light on how the EU should address the challenges it faces today in the social, economic and political spheres. 
Table 2 provides a synthesised vision of the ideals in their dynamic dimension:

Table 2 - Original ideals, present challenges, future possibilities

\begin{tabular}{|l|l|l|l|l|}
\hline $\begin{array}{l}\text { Sphere } \\
\text { Stage }\end{array}$ & Social & Economic & Political & Cultural \\
\hline Original ideal & Peace & Prosperity & Supranationalism & $\begin{array}{l}\text { Bible \& } \\
\text { Enlightenment }\end{array}$ \\
\hline $\begin{array}{l}\text { Present } \\
\text { Challenge }\end{array}$ & $\begin{array}{l}\text { Parallel } \\
\text { societies }\end{array}$ & Fragmentation & Impasse & Radicalisation \\
\hline $\begin{array}{l}\text { Future } \\
\text { possibility }\end{array}$ & $\begin{array}{l}\text { Intercultural } \\
\text { blending }\end{array}$ & Flexibility & Analogical unity & $\begin{array}{l}\text { Inclusive } \\
\text { public sphere }\end{array}$ \\
\hline
\end{tabular}

\section{Social blending: interculturalism}

In the social sphere, interculturalism would translate into mutual openness and a certain degree of blending. ${ }^{58}$ Bouchard \& Taylor's proposal for Quebec, ${ }^{59}$ Zamagni's and Donati's Italian perspective, ${ }^{60}$ and Fornet-Betancourt and Beuchot Latin American point of view are examples in that direction. ${ }^{61}$

In the interculturalist scenario the initially distant cultural positions, through communication and exchange, slowly achieve degrees of blending, in a way that after some time they have created a new, richer culture together-one that everybody can claim to have contributed to building. Two prerequisites for intercultural dialogue are: acknowledgement that individuals and human groups (including the majority or recipient group in a country) are "cultural"-i.e. possessing culture; ${ }^{62}$ and communication with the aid of a "transcultural grammar" based on a basic notion of equality among human beings. ${ }^{63}$ This transcultural grammar, which Beuchot has pinned down to a certain conception of the human rights, ${ }^{64}$ could help create a new, blended culture, common to all European citizens, and therefore capable of serving as a source of meaning and cohesion to all of them.

Perhaps a first step in order to start an open and sincere dialogue with Muslims-and to ask the same from them-is the acknowledgement that the sources of European political culture include the Enlightenment and religion. Realisation of religion's influence in the political culture of both-secular and religious Europeans-might, after all, work as a bridge for reciprocal understanding, communication and harmonious integration. ${ }^{65}$ In Davie's words "Islam must adapt to Europe...but Europe must also adapt to Islam."66 
A second step could be for all those living permanently in Europe to realise that they might have to be with each other for a long time. This realisation should reinforce the view that dialogue is necessary.

A third step, already sketched above, is the creation of new ways of life- and political culture-together, as a result of productive dialogue. Casanova, Beuchot, van Leeuwen and others, have suggested possible avenues. ${ }^{67}$ What those proposals have in common is the idea that respect and tolerance are not enough: they are only the beginning. Social integration will only happen through exchange and interaction among the different cultural groups. And the result will be a new, richer, and common culture. Dialogue goes beyond discourse, to new ways of life together. ${ }^{68}$ Table 3 presents these ideas in a schematic way:

Table 3 - Conceptual location of interculturalism

\begin{tabular}{|l|l|l|l|}
\hline Theory & Monoculturalism & Multiculturalism & Interculturalism \\
\hline Tool & Assimilation & Tolerance & Exchange \\
\hline Situation & Alienation & Isolation & Integration \\
\hline Result & Homogenised society & Parallel societies & Blended society \\
\hline
\end{tabular}

\section{Flexible economic cooperation}

European integration in general and economic integration in particular should also be conceived in a different way, adapted to the new situation in which the European project finds itself today. As I have tried to show in the first section, this project was not a purely economic arrangement based on self-interest and otherwise ignorant or mindless of whom the partners were. Economic cooperation was a tool, not the main goal. Even in the EU as it is today-let alone one with more members-economic cooperation is already problematic and governance very difficult. ${ }^{69}$ There has been talk among European leaders about reforming the Treaty of Lisbon to deal with indebted eurozone States in crisis (like Greece). ${ }^{70}$ In face of this situation, Vivien Schmidt plausibly has advanced the idea of differentiated cooperation, a "Europe à la carte." "71

Schmidt observes that in practice the EU does not always work in a uniform and unanimous manner. She points out that there are different conceptions of the EU-its identity-that cannot be easily reconciled. ${ }^{72} \mathrm{~A}$ "Menu Europe"' may be in part a description of how the EU is developing at least in certain areas, as well as a normative position on the possible way ahead. After all, the European project started thanks to a sectoral agreement of a small group of countries, for the joint production of coal and steel: with time new fields of cooperation and countries were added 
to the original "menu." Today, differentiated-or "flexible"—cooperation might appear as a somewhat chaotic avenue for the European project, but it could bring new life to it, provided some changes in the paradigm of political integration were considered, as we shall see next. ${ }^{73}$

\section{Analogical unity for the supranational polity}

Under conditions of social interculturalism and flexible economic integration, the EU regime should be conceived in alternative terms too, corresponding to a stateless, supranational polity ${ }^{74}$ that motivates an allegiance weaker than, and subordinated to, the national kind. ${ }^{75}$ Its source of cohesion or unity could have a certain resemblance with the national one as well, without being exactly similar, but only "analogical". In order to illustrate the idea of analogical unity I would like to bring up Joseph Weiler's Principle of Constitutional Tolerance (PCT). ${ }^{76}$ This principle is an example, in the realm of constitutional law, of analogical unity, and it has been already at work throughout the history of European integration. ${ }^{77}$

In the European constitutional landscape, Weiler notes, "Community norms trump conflicting Member State norms." This hierarchy however, "is not rooted in a [top to bottom], but rather on a "bottom-to-top hierarchy of authority and real power." For Weiler this singularity shows the Grundnorm of the European constitutional construct. The political organisation of the EU in good part reflects this principle and defies the normal premise of constitutionalism.

Under the PCT, the member states accept the European constitutional discipline not because they are subordinated to a federal state as part of its constitutional demos. They accept it as "an autonomous voluntary act, endlessly renewed on each occasion, of subordination," in areas governed by a European norm which is the aggregated expression of other political communities. This "creates in itself a different type of political community, one unique feature of which is that very willingness to accept a binding discipline which is rooted in, and derives from a community of others." ${ }^{178}$

The PCT reflects a peculiar polity and a sort of unity that is like the unity of a federal state, but not exactly; it is partly similar and partly different-it is "analogical." ${ }^{\text {" }}$ Europe is not a demos, but a collection of demoi. The European demoi have in fact paid allegiance to the European project as it has been, always as a community of peoples, never as a people. A European polity based on this analogical unity is more likely to stay together, but it is also more desirable because it respects the autonomy of the parts, it is a real "unity in diversity". If national diversity is a treasure to Europe-in its languages, just to mention one example-then analogical unity ought to be the way of keeping the polity 
together.

Analogical unity, as the PCT shows, relies on something different to a legal obligation. It presupposes willingness, in other words a free assent to act even if there is no punishment (say, a fee) for not acting. Solidarity, for example, cannot be dictated by law and presupposes such free assent. This element of freedom and solidarity was very much present in the foundational years, animated by the ideals that set in motion the European community of states and peoples. ${ }^{80}$ In a democratic polity equality finds formal expression in citizenship and actual realisation in an inclusive public sphere. To that we now turn.

\section{An inclusive public sphere}

In the second part of this paper we examined three very significant sources informing the current political culture of Europe: the Enlightenment, Christianity and Islam. Representatives of these streams have already contributed interesting ideas to the discussion of the place of worldviews (secularism and religions included) in the public sphere. ${ }^{81}$ In comparison with the secular majority, Christians and Muslims in Europe are minorities, and they know it. For all their long history of coexistence and conflict, ${ }^{82}$ they are in dialogue based on some common ground. ${ }^{83}$ This, says Davie, is not always obvious for "the secular elites," ${ }^{84}$ who face the double challenge of recognising that the majority cultural stand is a cultural stand, on the one hand; and that religious positions, including Islam should be recognised, on the other ${ }^{85}$

The way is certainly not easy, but neither is it impossible. History provides evidence of intolerance and persecution on religious grounds, under Christian, Muslim, or secularist regimes. ${ }^{86}$ The social blending at which interculturalism aims (see above) is pursued in part through dialogue that occurs in the public sphere. ${ }^{87}$ Interesting ideas for an inclusive public sphere have come from thinkers pertaining to diverse cultural political traditions. ${ }^{88}$ Due to lack of space here I will refer to only one. ${ }^{89}$

Habermas distinguishes between "the normative demands of a liberal order" and "the functional social imperatives of modernization", which among other things demands "the secularization of state authority." Secular citizens must adjust to a new situation, that of post-secular societies, where religious communities continue to exist (i.e. did not disappear according to the Modern myth). Secular and religious citizens must learn to live in disagreement about certain issues with each other. ${ }^{91}$ This realisation must motivate citizens of either group not only to speak in terms that the other may understand, but also to help those with a 
different worldview to "translate" their claims into a language understood by all.

In order for secular citizens not to become secularist (as for religious citizens not to become fundamentalist), they must adopt a self-critical view of the limits of secular reason (as religious citizens must be critical of religion too). ${ }^{92}$ Or in Ratzinger's words, "religion must continually allow itself to be purified and structured by reason," while (secular) reason can benefit as well from the enrichment of faith and religion. ${ }^{93}$

What interculturalism is for the social context, inclusiveness in the public sphere is for the cultural realm. Even a supranational, stateless polity needs a link among its members to keep it together. That link can be strengthened through an inclusive public sphere, whose most prominent outcome is a common political culture.

\section{Conclusion: allegiance and identity in evolution}

One of the theories about why dinosaurs became extinct relates these formidable creatures' incapacity to diversify before changing conditions. ${ }^{94}$ The European project has been greatly successful so far, but whether it can expect a better fate than that of dinosaurs in the face of the present crisis is still an open question. Europe's "ecosystem", its local and global environment, is changing rapidly. Europe must change too, and this time with a much prominent participation from its citizens. Bringing to mind the original ideals can illuminate ways to face the present challenges. But the result will be altogether different. A Europe which evolves towards intercultural social blending; flexible economic cooperation; analogical political unity; and a public sphere inclusive of the different cultural streams that matter to its citizens today; such Europe will be worth fighting for.

\section{References}

Anderson, Carl A. . Beyond a House Divided: The Moral Consensus Ignored by Washington, Wall Street, and the Media. Paperback ed: Image, 2010.

Bancroft, A. Roma and Gypsy-Travellers in Europe: Modernity, Race, Space, and Exclusion: Ashgate, 2005.

Bauböck, Rainer. "Why European Citizenship? Normative Approaches to Supranational Union." Theoretical Inquiries in Law 8, no. 2 (2007): 453-88.

Begg, Iain, Joseph Weiler, and John Peterson. Integration in an Expanding European Union : Reassessing the Fundamentals. Oxford: Blackwell, 2003. 
Bellamy, R \& Warleigh, A. "From an Ethics of Integration to an Ethics of Participation: Citizenship and the Future of the European Union." Millennium: Journal of International Studies 27, no. 3 (1998 ): 447-70.

Benedict, Pope. Without Roots : The West, Relativism, Christianity, Islam / Joseph Ratzinger Now Pope Benedict Xvi, Marcello Pera ; Foreword by George Weigel ; Translated by Michael F. Moore. Edited by Marcello Pera, George Weigel and Michael F. Moore. New York, N.Y. :: Basic Books, 2006.

Beuchot, Mauricio. En El Camino De La Hermenéutica Analógica, Aletheia. Salamanca: San Esteban, 2005.

- - Interculturalidad Y Derechos Humanos, Filosofía. México, D. F.: Universidad Nacional Autónoma de México; Siglo XXI, 2005.

Bhutto, Benazir. Reconciliation : Islam, Democracy, and the West. 1st ed. New York: Harper, 2008.

Bode, Kim and others. "Sarrazin's Integration Demagoguery Has Many Followers. The Man Who Divided Germany." Spiegel Online,no. 9 June

(2010), http://www.spiegel.de/international/germany/0,1518,715876,00.ht $\underline{\mathrm{ml}}$.

Casanova, José. "Religion, European Secular Identities, and European Integration." Eurozine (2004), http://www.eurozine.com/articles/200407-29-casanova-en.html\#

_-_. "The Secular and Secularisms." Social Research 76, no. 4 (2009): 1049-66.

Charlemagne. "Game, Set and Match to Angela." The Economist (2010), http://www.economist.com/blogs/charlemagne/2010/10/eurozone governance.

- - "God Meets the Lawyers." The Economist (2003), http://www.economist.com/node/2265997.

Commission, European. "Consolidated Versions of the Treaty on European Union and the Treaty on the Functioning of

the European Union, and Charter of Fundamental Rights of the European Union." Official Journal of the European Union (2010), http://eurlex.europa.eu/LexUriServ/LexUriServ.do?uri=O]:C:2010:083:FULL:EN :PD $\mathrm{F}$.

Commission, The Pontifical Biblical. "The Jewish People and Their Sacred Scriptures in the Christian Bible." Vatican City: Libreria Editrice Vaticana, 2002.

Council of Europe, Ministers of Foreign Affairs. "White Paper on Intercultural Dialogue "Living Together as Equals

in Dignity"." (2008),

http://www.coe.int/t/dg4/intercultural/source/white\%20paper final $r$ evised en.pdf.

Davie, Grace. "Religion in Europe in the 21 Century: The Factors to Take 
into Account." European Journal of Sociology 47, no. 02 (2006): 271-96.

Deely, John "The Absence of Analogy." The Review of Metaphysics 55, no. 3 (2002): 521-50.

Di Lieto, Giovanni. "Allegiance and Identity in a Globalised World." In Connecting International Law with Public Law, edited by Nolan Rubenstein, Jenkins. Cambridge: Cambridge University Press, 2010.

Donati, Pierpaolo. "Beyond the Dilemmas of Multiculturalism: Recognition through 'Relational Reason'." International Review of Sociology 19, no. 1 (2009): 55-82.

- - - "Relational Sociology and the Globalized Society." In Paper presented at the ESA 10th Conference. Geneva, 2011.

Dougherty, Jude P. . "The Fragility of Democracy." Modern Age, no. Spring 2006 (2006): 119-29.

Dyson, K., and A. Sepos. Which Europe?: The Politics of Differentiated Integration: Palgrave Macmillan, 2010.

"Economic Sanctions? Yes, Please." The Economist Online,no. 30 September 2010 (2010), http://www.economist.com/node/17149082.

"Enhanced Cooperation." Europa Website (2011), http://europa.eu/legislation_summaries/institutional_affairs/treatie s/ nice treaty/nice treaty cooperations en.htm.

"Euro Follies." The Economist Online, no. 23 September (2010), http://www.economist.com/node/17095329?story id=17095329.

"Europe Day." Europa website (2011), http://europa.eu/abc/symbols/9- may/index en.htm.

Fischer, Gabriel Motzkin \& Yochi, ed. Religion and Democracy in Contemporary Europe. London: Alliance Publishing Trust, 2008.

Fligstein, Neil. Euroclash: The EU, European Identity, and the Future of Europe. Oxford, New York: Oxford University Press, 2008.

Fornet-Betancourt, Raúl. "Intercultural Philosophy from a Latin American Perspective Worldviews and Cultures." edited by Nicole Note, Raúl Fornet-Betancout, Josef Estermann and Diederik Aerts, 149-61: Springer Netherlands, 2009.

Froese, P. The Plot to Kill God: Findings from the Soviet Experiment in Secularization: University of California Press, 2008.

Gabriel, Theodore. Christian Citizens in an Islamic State : The Pakistan Experience / Theodore Gabriel. Aldershot ; Burlington, Vt. :: Ashgate, 2007.

Goldman, D. Globalisation and the Western Legal Tradition. Recurring Patterns of Law and Authority., Law in Context. Cambridge: Cambridge University Press, 2007.

Habermas-Derrida. "February 15, or What Binds Europeans Together: A Plea for a Common Foreign Policy, Beginning in the Heart of Europe." Constellations 10, no. 3 (2003): 291-97.

Habermas, J. "Equal Treatment of Cultures and the Limits of Postmodern 
Liberalism*." Journal of Political Philosophy 13, no. 1 (2005): 1-28.

. "Religion in the Public Sphere." European Journal of Philosophy 14, no. 1 (2006): 1-25.

- - - The Structural Transformation of the Public Sphere: An Inquiry into a Category of Bourgeois Society. MIT Press, 1991.

Habermas, Jürgen. An Awareness of What Is Missing - Faith and Reason in a Post-Secular Age. Hardback ed. Cambridge: Polity Press, 2010.

Habermas, Jürgen, and Joseph Ratzinger. The Dialectics of Secularization: On Reason and Religion. San Francisco: Ignatius Press, 2006.

Hancock, I.F. We Are the Romani People: University of Hertfordshire Press, 2002.

Heyward, Mark. "From International to Intercultural." Journal of Research in International Education 1, no. 1 (2002): 9-32.

"Il Dialogo Tra Le Reti Interculturali - Questioni E Prospettive." Paper presented at the Colloquio internazionale delle reti interculturali, Messina, Italia, 23 - 25 Ottobre 20082008.

"In from the Wilderness." The Economist Online,no. 1 Oct 2010 (2010), http://www.economist.com/blogs/newsbook/2010/10/dutch politic s.

Israely, Jeff. "Vatican Launches Catholic-Islamic Dialogue." TIME no. 4 Nov (2008),

http://www.time.com/time/printout/0,8816,1856185,00.html.

JHHW. "Editorial." European Journal of International Law 21, no. 1 (2010): 1 6.

Jiménez Lobeira, Pablo C. "EU Analogical Identity - or the Ties That Link (without Binding)." Australia National University Centre for European Studies Briefing Paper Series 1, no. 2 (2010).

_-_. "Exploring an Analogical Citizenship for Europe." Open Citizenship - The Journal 1, no. Autumn 2010 (2010): 28-49.

Justenhoven, Heinz-Gerhard. "Peace Ethics of Pope John Paul Ii, The." U. St. Thomas L. J. 3 (2005-2006).

Kalyvas, Stathis N., and Kees van Kersbergen. "Christian Democracy." Annual Review of Political Science 13, no. 1 (2010): 183-209.

Lester, Eva. "Disenfranchising the Disenfranchised: The Foreclosure of Allegiance, the Fixing of a Faceless Identity and the Legacy of the Nineteenth Century Globalisation." In Allegiance and Identity in a Globalised World, edited by Nolan Rubenstein, Jenkins. Australian National University: Centre for International and Public Law, 2010.

Liégeois, J.P., and Council of Europe. Roma in Europe: Council of Europe Pub., 2007.

Lloyd, Graeme T, Katie E Davis, Davide Pisani, James E Tarver, Marcello Ruta, Manabu Sakamoto, David W.E Hone, Rachel Jennings, and Michael J Benton. "Dinosaurs and the Cretaceous Terrestrial Revolution." Proceedings of the Royal Society B: Biological Sciences 275, no. 1650 (2008): 2483-90.

Mahony, Honor. "EU Citizens No Longer See Benefits of Internal Market, 
Barnier Says." Euobserver.com,no. 22.09.2010 @ 17:41 CET (2010), http://euobserver.com/19/30845

Maull, Hanns W. "Europe's Decline, Continued." Survival 53, no. 6 (2011): 197-204.

McCormick, John. Understanding the European Union: A Concise Introduction. 4th ed, The European Union Series. New York: Palgrave Macmillan, 2008.

Mendieta, Eduardo. "Rethinking Secularism: A Postsecular World Society?: An Interview with Jürgen Habermas." In The Immanent Frame Secularism, religion and the public sphere, edited by Jonathan VanAntwerpen, 2010.

Meyer, J. La Cristiada: The Mexican Government's Persecution of the Church: Square One Pub, 2009.

"Muslims in Germany." Der Spiegel, 2010.

Nelsen, Brent F., James L. Guth, and Cleveland R. Fraser. "Does Religion Matter? Does Religion Matter?: Christianity and Public Support for the European Union." European Union Politics 2, no. 2 (2001): 191-217.

Nicolaïdis, Kalypso. "The Jcms Annual Review Lecture Sustainable Integration: Towards EU 2.0?" JCMS: Journal of Common Market Studies 48 (2010): 21-54.

Nielsen, J. rgen S. Yearbook of Muslims in Europe. Leiden ; Boston: Brill, 2009. O'Mahony, Anthony. "The Vatican and Europe: Political Theology and Ecclesiology in Papal Statements from Pius Xii to Benedict Xvi." International Journal for the Study of the Christian Church 9, no. 3 (2009): 177 - 94.

Panikkar, Raimon. "Decálogo, Cultura E Interculturalidad." Cuadernos interculturales 4, no. 6 (2006): 129-30.

-_- "Religion, Philosophy and Culture." Forum for Intercultural

Philosophy

1 (2000).

Patel, Kiran Klaus. "Christian Democracy and the Origins of European Union."

The English Historical Review CXXIV, no. 509 (2009): 1013-14.

Paterson, Tony. "Swiss Referendum Set to Support Deportation of Foreign

Criminals." The Independent

(2010),

http://www.independent.co.uk/news/world/europe/swiss-

referendum-set-to-support-deportation-of-foreign-criminals2144024.html.

Pop, Valentina. "Euro 'Bad for the Economy,' Say French, Germans, Spaniards." Euobserver.com,no. 15 September 2010, 17:50 CET (2010), http://euobserver.com/9/30809.

Puhl, Jan. "Unwanted in France, Unloved in Romania - a Desperate Homecoming for Deported Roma." Spiegel Online, no. 31, August (2010), 
http://www.spiegel.de/international/europe/0,1518,714649,00.html. Ratzinger, Joseph. Christianity and the Crisis of Cultures. Translated by Brian McNeil. Hardback ed. San Francisco: Ignatius, 2006.

-C- Europe Today and Tomorrow - Addressing the Fundamental Issues. Translated by Michael J Miller. Hardback ed. San Francisco: Ignatius, 2007.

- - - Truth and Tolerance - Christian Belief and the World Religions.

Translated by Henry Taylor. San Francisco: Ignatius, 2004.

Ratzinger, Jürgen Habermas and Joseph. Dialectics of Secularization - on Reason and Religion Translated by Brian McNeil. Hardback ed. San Francisco: Ignatius Press, 2006.

Richard Bellamy, Dario Castiglione. "Lacroix's European Constitutional Patriotism: A Response." Political Studies 52, no. 1 (2004): 187-93.

Schmidt, Vivien A. "L'europe À La Carte ?" Telos (2008), http://www.teloseu.com/fr/article/l europe a la carte.

Schuman, Robert. For Europe. Translated by Foundation Robert Schuman. First ed. Paris: Nagel Editions 2010.

Shelledy, Robert B. "The Vatican's Role in Global Politics." SAIS Review XXIV, no. 2 (2004): 149-62.

Shuman, Robert. "Declaration 9 May 1950." Selection of texts concerning institutional matters of the Community from 1950 to 1982 (1950), http://www.ena.lu/schuman declaration_paris 1950-2-613.

"Signature of the Accession Treaty of the European Union (EU) with Croatia: Background Note." Europa.eu (2011), http://europa.eu/rapid/pressReleasesAction.do?reference=MEMO/1 $1 / 883$.

Smee, Jess. "The EU Has Finally Opened the Door to Economic Union." Spiegel Online,no. 30 September 2010, 2:54pm (2010), http://www.spiegel.de/international/europe/0,1518,720479,00.html

"Soft Centre. Can a Currency Survive without a State?". The Economist Online, no. 11 Jun (2009), http://www.economist.com/node/13767419.

Taylor, C. A Secular Age: Belknap Press of Harvard University Press, 2007. Taylor, Gérard Bouchard \& Charles. "Building the Future - a Time for Reconciliation." 2008.

"Traité De Paris." Titre II, Des institutions de la Communauté(1951), http://mjp.univ-perp.fr/europe/1951ceca2.htm.

Traynor, Ian. "Sweden Joins Europe-Wide Backlash against Immigration." guardian.co.uk, Friday 24 September (2010), http://www.guardian.co.uk/world/2010/sep/24/sweden-immigratio n- far-right-asylum.

van Leeuwen, Bart. "Dealing with Urban Diversity: Promises and Challenges of City Life for Intercultural Citizenship." Political Theory 38, no. 5 (2010): 631-57.

Villagrasa, Jesús. "Cincuenta Años De Integración Europea. De Los Tratados De Roma Al Tratado Constitucional." Ecclesia. Revista de 
cultura católica. XXI, no. 1 (2007): 63-90.

- - - Identidad Y Diálogo. El Problema De La Universalidad Y La

Particularidad Del Cristianismo Y De Europa, Colección “Estudios

Ocasionales: Universidad Anáhuac México Sur, 2007.

Weiler, J. H. H. "Europe: The Case against the Case for Statehood." European Law Journal 4, no. 1 (1998): 43-62.

. "The Transformation of Europe." The Yale Law Journal 100, no. 8 (1991): 2403-83.

Weiler, Joseph. "The Community System: The Dual Character of Supranationalism." Yearbook of European Law 1, no. 1 (1981): 267-306.

- - . The Constitution of Europe: Do the New Clothes Have an Emperor? And Other Essays on European Integration. UK: Cambridge University Press, 1999.

- - - Un' Europa Cristiana : Un Saggio Esplorativo. Milano: RCS Libri, 2003. Willisher, Kim. "France's Front National Enjoys Renaissance under Marine Le Pen." The Guardian, 6 November 2011 19.13 GMT 2012.

"The Winner Doesn't Take It All. The Far Right Emerge as the Big Winners in Sweden's Election.". The Economist Online,no. 23 Sept 2010 (2010), http://www.economist.com/node/17103689.

Zucca, Lorenzo "A Comment on Lautsi." EJIL: Talk!,no. 19 Mar 2011 (2011), http://www.ejiltalk.org/a-comment-on-lautsi/.

\section{Notes}

'I would like to sincerely thank Prof. Tom Campbell, Prof. Simon Bronitt, Prof. Kim Rubenstein, Dr John Besemeres, Dr Anne Schwenkenbecher, Dr Vito Breda, Dr Dorota Gozdecka, Dr Marìa Teresa Gil-Bazo, Dr Matthew Harvey, Dr Christian Wicke; the participants at the conference on European solidarity organised by the Centre of Excellence Foundations of European Law and Polity, held at the University of Helsinki, September 2011 and Fiona Jenkins for very helpful comments and suggestions. A later version of this draft appeared in: Jenkins, Nolan \& Rubenstein (eds), Allegiance and Identity in a Globalised World, Cambridge University Press, 2014.

${ }^{2}$ Centre for European Studies (Australian National University), and Centre for Applied Philosophy and Public Ethics (Charles Sturt University), Canberra Australia.

${ }^{3}$ Elsewhere I have suggested that if there is a European identity, it a nuanced one, much less intense than national identities, and subordinated to them: Pablo C Jiménez Lobeira, "EU Analogical Identity - or the Ties That Link (without Binding)," Australia National University Centre for European Studies Briefing Paper Series 1, no. 2 (2010): 250 -52.

${ }^{4}$ Regarding the sense of belonging.

5Joseph Weiler, The Constitution of Europe: Do the New Clothes Have an Emperor? And Other Essays on European Integration (UK: Cambridge University Press, 1999), 244. ${ }^{6}$ Robert Shuman, "Declaration 9 May 1950," Selection of texts concerning institutional matters of the Community from 1950 to 1982(1950),

http://www.ena.lu/schuman_declaration_paris_1950-2-613. For those less familiar with the history of the EU, the Schuman declaration is considered the starting point of the creation of European integration. The declaration was made on the 9th of May 1950. The celebration

has become one of the "symbols" of the EU ("Europe Day")."Europe Day," Europa website(2011), http://europa.eu/abc/symbols/9-may/index_en.htm.

'Weiler, The Constitution of Europe, 239. 
${ }^{8}$ Joseph Ratzinger, Europe Today and Tomorrow - Addressing the Fundamental Issues, trans. Michael J Miller, Hardback ed. (San Francisco: Ignatius, 2007), 35-44.

'Joseph Weiler, Un' Europa Cristiana : Un Saggio Esplorativo (Milano: RCS Libri, 2003), 11521. Throughout this paper references to the Biblical tradition and to Christian democracy refer as much to the moral influx of Christianity on the social, economic and political life of Europe, as to that of Judaism. Apart from the role that Judaism has played in Europe on its own right, Christianity cannot be understood without strong (essential) reference to Judaism, both in theological and historical terms. See: The Pontifical Biblical

Commission, "The Jewish People and Their Sacred Scriptures in the Christian Bible."

(Vatican City: Libreria Editrice Vaticana, 2002),

http://www.vatican.va/roman_curia/congregations/cfaith/pcb_documents/rc_con_cfaith_ do c_20020212_popolo-ebraico_en.html\#INTRODUCTION.

${ }^{10}$ For schematic purposes those two traditions are mentioned separately here. But this does not mean that they are entirely independent from each other. There is abundant literature to show the relation and mutual influence between these two sources of Western culture. See for instance: Jürgen Habermas and Joseph Ratzinger, The Dialectics of Secularization: On Reason and Religion (San Francisco: Ignatius Press, 2006)., D.

Goldman, Globalisation and the Western Legal Tradition. Recurring Patterns of Law and Authority., Law in Context (Cambridge: Cambridge University Press, 2007)., and C. Taylor, A Secular Age (Belknap Press of Harvard University Press, 2007). I thank Dr Matthew Harvey for helpful comments related to these issues.

"Weiler does not use a single adjective to qualify the ideals. I have introduced them to contextualise the ideals better and to carry out the analysis along time.

${ }^{12}$ Weiler, The Constitution of Europe, 241. I take it that Weiler wants to underline that some of the founders of the EU were religious people (practising Christians). This does not imply by any means religion was the only element inspiring those ideals. The project was clearly, from the beginning, framed under modern conceptions of tolerance, progress and others come from the Enlightenment as well. I thank Dr Breda for useful comments in this respect.

${ }^{13}$ Ratzinger points out that the common basis for the pursuit of this ideal lay, among other things, in the cultural background of Europe contained in the traditions of Christianity and the Enlightenment (Ratzinger, Europe Today and Tomorrow, 36-36, 77-79.). See the "cultural presuppositions" section below.

${ }^{14}$ Weiler, The Constitution of Europe, 245.

${ }^{15}$ Ibid.

${ }^{16}$ Ibid.

${ }^{17}$ Ibid., 246.

${ }^{18}$ Ibid., 250.

${ }^{19}$ In Weiler's words: “...the Unity vision, the United States of Europe vision, has really posited as its ideal type, as its aspiration, a statal Europe, albeit of a federal kind...The classical model of international law is a replication at the international level of a liberal theory of the state. The state is implicitly treated as the analogue, on the international level, to the individual within a domestic situation...In the supranational vision, the community as a transnational regime will not simply be a neutral arena in which states...seek to maximize their benefits but...to create a regime which seeks to tame the national interest with a new discipline...which eliminates the excesses of narrow statal "national interest..." Ibid., 250-52.

${ }^{20}$ "Supranationalism" is, by the way, much more than only a term of scholarly analysis. It was used profusely in the original vision of the European project (see for instance Schuman's remarks in footnote 14). It also was included not less than in the foundational treaty of European integration, to start the European Coal and Steel Community, the Treaty of Paris (18 April 1951) in its Article 9. See: "Traité De Paris," Titre II, Des institutions de la Communauté(1951), http://mjp.univ-perp.fr/europe/1951ceca2.htm. ${ }^{21}$ - -, , The Constitution of Europe, 91-96.

${ }^{22}$ Ibid. In a context wider than that of the EU, the Council of Europe (COE), which preceded the EU, has had an important role upholding these values. 
${ }^{23}$ I have touched on this issue in: Pablo C Jiménez Lobeira, "Exploring an Analogical Citizenship for Europe," Open Citizenship - The Journal 1, no. Autumn 2010 (2010): 36-42.

${ }^{24}$ Borrowing an interesting term used in an analysis of today's American culture. See: Carl A. Anderson, Beyond a House Divided: The Moral Consensus Ignored by Washington, Wall Street, and the Media, Paperback ed. (Image, 2010).

${ }_{25}^{25}$ See: Habermas and Ratzinger, The Dialectics of Secularization: On Reason and Religion, 77-

78. Here, Ratzinger speaks about the "pathologies" both of religion and of reason. For him, the interaction between the two spheres enriches both.

${ }^{26}$ Habermas-Derrida, "February 15, or What Binds Europeans Together: A Plea for a

Common Foreign Policy, Beginning in the Heart of Europe," Constellations 10, no. 3 (2003): 295-97.

${ }^{27}$ This importance of Christianity for European integration has been brought to attention, among others, by Shelledy Robert B Shelledy, "The Vatican's Role in Global Politics," SAIS Review XXIV, no. 2 (2004).; O'Mahony Anthony O'Mahony, "The Vatican and Europe: Political Theology and Ecclesiology in Papal Statements from Pius Xii to Benedict Xvi," International Journal for the Study of the Christian Church 9, no. 3 (2009).; Nelsen et al. Brent F. Nelsen, James L. Guth, and Cleveland R. Fraser, "Does Religion Matter? Does Religion Matter?: Christianity and Public Support for the European Union," European Union Politics 2, no. 2 (2001).; Dougherty Jude P. Dougherty, "The Fragility of Democracy," Modern Age, no. Spring 2006 (2006). Villagrasa Jesús Villagrasa, "Cincuenta Años De Integración Europea. De Los Tratados De Roma Al Tratado Constitucional.," Ecclesia. Revista de cultura católica. XXI, no. 1 (2007).; Patel Kiran Klaus Patel, "Christian Democracy and the Origins of European Union," The English Historical Review CXXIV, no. 509 (2009)., Kalivas \& van Kersbergen Stathis N. Kalyvas and Kees van Kersbergen, "Christian Democracy," Annual Review of Political Science 13, no. 1 (2010).

${ }^{28}$ Both in its liberal, and its social-democratic versions. As for the case of Christianity, it might be objected to this vision in that to present it as a unified front might overlook deep divisions between different groups, for instance Protestant and Catholic Christians. Yet arguably - at least in the political realm-Christian Democracy symbolises the reconciliation between them. See: José Casanova, "Religion, European Secular Identities, and European Integration," Eurozine(2004),

http://www.eurozine.com/articles/2004-07-29-casanova- en.html\# Finally the Christian spectrum, especially after 2004, is wider than Western Christianity: it includes as well Eastern Christianity (Orthodox and other churches). I thank Professor Bronitt for helpful comments on this topic.

${ }^{29}$ Neil Fligstein, Euroclash: The EU, European Identity, and the Future of Europe (Oxford, New York: Oxford University Press, 2008), 1-6.

${ }^{30}$ Considering as the genesis of the project the $9^{\text {th }}$ of May 1950.

${ }^{31}$ Croatia is poised to become the $28^{\text {th }}$ member in July 2013 , pending Treaty ratification

by the 27 and Croatia itself in the following months. See: "Signature of the Accession Treaty of the European Union (EU) with Croatia: Background Note," Europa.eu(2011), http://europa.eu/rapid/pressReleasesAction.do?reference=MEMO/11/883.

${ }^{32}$ Nikolaïdis prefers to see the EU as in its "adolescence." Kalypso Nicolaïdis, "The Jcms Annual Review Lecture Sustainable Integration: Towards EU 2.0?," JCMS: Journal of Common Market Studies 48(2010): 23.

${ }^{33}$ In August and September 2010, a heated controversy arose around the decision by the French government to deport hundreds of Roma people. See: Jan Puhl, "Unwanted in France, Unloved in Romania - a Desperate Homecoming for Deported Roma," Spiegel Online, no. 31 August 2010, 2:18pm (2010),

http://www.spiegel.de/international/europe/0,1518,714649,00.html. Roma people are the largest minority group in Europe (between 10 and 12 million in the EU). See: J.P. Liégeois and Council of Europe, Roma in Europe (Council of Europe Pub., 2007), 77-86. A. Bancroft, Roma and Gypsy-Travellers in Europe: Modernity, Race, Space, and Exclusion (Ashgate, 2005). and especially I.F. Hancock, We Are the Romani People (University of Hertfordshire Press, 2002). I thank Dr Schwenkenbecher and Dr Breda for very valuable comments and suggestions on this topic. 
${ }^{34}$ My translation.

35 "Muslims in Germany," (Der Spiegel, 2010).

${ }^{36} \mathrm{Kim}$ and others Bode, "Sarrazin's Integration Demagoguery Has Many Followers. The Man Who Divided Germany," Spiegel Online, no. 9 June 2010 (2010), http://www.spiegel.de/international/germany/0,1518,715876,00.html.

37 "In from the Wilderness," The Economist Online, no. 1 Oct 2010 (2010), http://www.economist.com/blogs/newsbook/2010/10/dutch_politics. 38 "The Winner Doesn't Take It All. The Far Right Emerge as the Big Winners in Sweden's Election.," The Economist Online, no. 23 Sept 2010 (2010),

http://www.economist.com/node/17103689.

${ }^{39}$ Kim Willisher, "France's Front National Enjoys Renaissance under Marine Le Pen," The Guardian, 6 November 201119.13 GMT 2012.

${ }^{40}$ Ian Traynor, "Sweden Joins Europe-Wide Backlash against Immigration," guardian.co.uk, no. Friday 24 September 201018.15 BST (2010), http://www.guardian.co.uk/world/2010/sep/24/sweden-immigration-far-right-asylum. ${ }^{41}$ Though not an EU country, it is strongly connected with many of its members, and is experiencing similar phenomena. For instance the far-right Swiss People's Party (SVP) is promoting successfully the automatic expulsion of foreign (non-traditional Swiss resident) criminals. Tony Paterson, "Swiss Referendum Set to Support Deportation of Foreign Criminals," The Independent(2010), http://www.independent.co.uk/news/world/europe/swiss-referendum-set-to-supportdeportation-of-foreign-criminals-2144024.html.

${ }^{42}$ This is already happening in Russia, Ukraine and possibly other countries. I thank Dr John Besemeres for pointing out this information to me.

43 "Soft Centre. Can a Currency Survive without a State?," The Economist Online, no. 11 Jun 2009 (2009), http://www.economist.com/node/13767419.

44 "Euro Follies," The Economist Online, no. 23 September 2010 (2010),

http://www.economist.com/node/17095329?story_id=17095329. Nevertheless, as we shall see below, this fact can turn from symptom of a crisis to an opportunity of evolution in the configuration of Europe's identity.

45 "Economic Sanctions? Yes, Please," The Economist Online, no. 30 September 2010 (2010), http://www.economist.com/node/17149082.

${ }^{46}$ Jess Smee, "The EU Has Finally Opened the Door to Economic Union," Spiegel Online, no. 30 September 2010, 2:54pm (2010), http://www.spiegel.de/international/europe/0,1518,720479,00.html.

${ }_{47}$ Valentina Pop, "Euro 'Bad for the Economy,' Say French, Germans, Spaniards,"

Euobserver.com, no. 15 September 2010, 17:50 CET (2010), http://euobserver.com/9/30809. ${ }^{48}$ Honor Mahony, "EU Citizens No Longer See Benefits of Internal Market, Barnier Says," Euobserver.com, no. 22.09.2010 @ 17:41 CET (2010), http://euobserver.com/19/30845 ${ }^{49}$ Hanns W. Maull, "Europe's Decline, Continued," Survival 53, no. 6 (2011).

${ }^{50}$ I thank Dr Harvey for suggesting to me to specify the meaning of "federal". "Federation" can be understood at least in two ways: (1) as the combination of power sharing arrangements within an alliance, with the parts and the whole negotiating for more or less power in different areas, say education or military defence; or (2) as a political form, where "a" federation or a confederation could be part of a continuum, at which extremes could be conceived a completely centralised unitary state, on the one hand, and an intergovernmental organisation with no pool of sovereignty on the other. For Euro-statists as they are being presented here federation would mean "a state" (even if a state of states); whereas for supranationalists federation would mean "a stateless (or supranational) polity". For three different (in time and discipline, yet to a great extent compatible) accounts of supranationalism, see: Robert Schuman, For Europe, trans. Foundation Robert Schuman, First ed. (Paris: Nagel Editions 2010), 15-27., Joseph Weiler, "The Community System: The Dual Character of Supranationalism," Yearbook of European Law 1, no. 1 (1981)., J. H. H. Weiler, "The Transformation of Europe," The Yale Law Journal 100, no. 8 (1991)., _-_, "Europe: The Case against the Case for Statehood," European Law Journal 4, no. 1 (1998). And Rainer Bauböck, "Why European Citizenship? Normative 
Approaches to Supranational Union," Theoretical Inquiries in Law 8, no. 2 (2007): 455-64. In Bauböck's words, "The EU is a federal polity, but not a federal state." Bauböck, "Why European Citizenship? Normative Approaches to Supranational Union," 457.

${ }^{51}$ This is also the position of "Cosmopolitan-communitarianists" championed by Richard Bellamy. See: R \& Warleigh Bellamy, A, "From an Ethics of Integration to an Ethics of Participation: Citizenship and the Future of the European Union," Millennium: Journal of International Studies 27, no. 3 (1998 )., Dario Castiglione Richard Bellamy, "Lacroix's European Constitutional Patriotism: A Response," Political Studies 52, no. 1 (2004).. ${ }^{52}$ John McCormick, Understanding the European Union: A Concise Introduction, 4th ed., The European Union Series (New York: Palgrave Macmillan, 2008), 119-41.

${ }^{53}$ Charlemagne, "God Meets the Lawyers," The Economist(2003), http://www.economist.com/node/2265997.

${ }^{54} \mathrm{Cf}$ Taylor, A Secular Age, 548-56., and p.448: "And so we can come to see the growth of civilization, or modernity, as synonymous with the laying out of a closed immanent frame; within this civilized values develop, and a single-minded focus on the human good, aided by the fuller and fuller use of scientific reason, permits the greatest flourishing possible of human beings. Religion not only menaces these goals with its fanaticism, but it also

undercuts reason, which comes to be seen as rigorously requiring scientific materialism." ${ }^{55}$ José Casanova, "The Secular and Secularisms," Social Research 76, no. 4 (2009): 1059.

${ }^{56}$ Grace Davie, "Religion in Europe in the 21 Century: The Factors to Take into Account," European Journal of Sociology 47, no. 02 (2006): 288-89.

${ }^{57}$ Admittedly, a similar effect might come from those attached to their public, historic churches, but for whom 'seriously held belief is seen as a threat rather than an opportunity." Ibid.: 294. My idea in bringing to light some aspects of secularism in this

section is neither to denounce as "bad" a cultural position which constitutes the normal atmosphere of most Western societies today, nor to propose a return to past ages (say the pre-modern world, as the "good" one). As Taylor has admirably shown, "black or white" interpretations in this field serve little and are at best inaccurate. (Most people today would fall in a shade of "grey".) Taylor, A Secular Age, 594-617. Rather, my plea would be to envisage, using Taylor's terminology, an "open immanent frame". See section 3.4

${ }^{58}$ In a recent document of the CoE, there is recognition of this important shift in this analytical and normative paradigm: "Whilst driven by benign intentions, multiculturalism is now seen by many as having fostered communal segregation and mutual incomprehension, as well as having contributed to the undermining of the rights of individuals - and, in particular, women - within minority communities, perceived as if these were single collective actors. The cultural diversity of contemporary societies has to be acknowledged as an empirical fact... [T] he emerging interculturalist paradigm...takes from assimilation the focus on the individual; it takes from multiculturalism the recognition of cultural diversity. And it adds the new element, critical to integration and social cohesion, of dialogue on the basis of equal dignity and shared values." In: Ministers of Foreign Affairs Council of Europe, "White Paper on Intercultural Dialogue "Living Together as Equals in Dignity","(2008),

http://www.coe.int/t/dg4/intercultural/source/white\%20paper_final_revised_en.pdf. ${ }^{59}$ Gérard Bouchard \& Charles Taylor, "Building the Future - a Time for Reconciliation," (2008), 39.

${ }^{60}$ See: Pierpaolo Donati, "Beyond the Dilemmas of Multiculturalism: Recognition through 'Relational Reason'," International Review of Sociology 19, no. 1 (2009).

61 Raúl Fornet-Betancourt, "Intercultural Philosophy from a Latin American Perspective Worldviews and Cultures," ed. Nicole Note, et al., Einstein Meets Magritte: An Interdisciplinary Reflection on Science, Nature, Art, Human Action and Society (Springer Netherlands, 2009). Mauricio Beuchot, Interculturalidad Y Derechos Humanos, Filosofía (México, D. F.: Universidad Nacional Autónoma de México; Siglo XXI, 2005). 
${ }^{62}$ Inasmuch as every human being uses language for example, or has a worldview (and who does not?), human beings are "cultural". Dominant groups in nation states tend to see incoming groups with a different culture as "cultural", often not realising that the dominant group itself also possesses a particular culture which is not necessarily universal.

${ }^{63}$ Jesús Villagrasa, Identidad Y Diálogo. El Problema De La Universalidad Y La Particularidad Del Cristianismo Y De Europa, Colección “Estudios Ocasionales (Universidad Anáhuac México Sur, 2007). Another interesting perspective on transcultural values for intercultural dialogue: Raimon Panikkar, "Decálogo, Cultura E Interculturalidad," Cuadernos interculturales 4, no. 6 (2006). and - - , "Religion, Philosophy and Culture," Forum for Intercultural Philosophy 1(2000).

${ }^{64}$ Beuchot, Interculturalidad Y Derechos Humanos. To be clear, his particular proposal does not have the name of "interculturalism," but "cultural analogical pluralism, " which consists of the application of analogical hermeneutics to problems of unity and diversity arising in Latin American multicultural societies (especially Mexico).

${ }^{65}$ Moderate thinkers familiar with secularism, Christianity, Jewry, or Islam, such as Habermas, Taylor, Weiler or Talal Assad can be very helpful in fostering dialogue and exchange of ideas. See for instance: Jürgen Habermas and Joseph Ratzinger,

Dialectics of Secularization - on Reason and Religion trans. Brian McNeil, Hardback ed. (San Francisco: Ignatius Press, 2006)., Jürgen Habermas, An Awareness of What Is Missing - Faith and Reason in a Post-Secular Age, Hardback ed. (Cambridge: Polity Press, 2010).

${ }^{66}$ Davie, "Religion in Europe in the 21 Century: The Factors to Take into Account," 294. ${ }^{67}$ See notes 59 to 61 above, as well as: Gabriel Motzkin \& Yochi Fischer, ed. Religion and Democracy in Contemporary Europe (London: Alliance Publishing Trust,2008)., Taylor, "Building the Future - a Time for Reconciliation."; "Il Dialogo Tra Le Reti Interculturali Questioni E Prospettive", (paper presented at the Colloquio internazionale delle reti interculturali, Messina, Italia, 23 - 25 Ottobre 2008 2008); Mark Heyward, "From International to Intercultural," Journal of Research in International Education 1, no. 1 (2002); Beuchot, Interculturalidad Y Derechos Humanos. Heinz-Gerhard Justenhoven, "Peace Ethics of Pope John Paul Ii, The," U. St. Thomas L. J. 3(2005-2006).and Bart van Leeuwen, "Dealing with Urban Diversity: Promises and Challenges of City Life for Intercultural Citizenship," Political Theory 38, no. 5 (2010).One requisite among others for such dialogue should be readiness to learn from the other and the capacity of self-critique.

${ }^{68}$ One proposal to achieve this has been developed by Pierpaolo Donati, through what he calls "relational sociology".Donati, "Beyond the Dilemmas of Multiculturalism: Recognition through 'Relational Reason'." and Pierpaolo Donati, "Relational Sociology and the Globalized Society," in Paper presented at the ESA 10th Conference (Geneva2011).

${ }^{69} \mathrm{Admittedly}$, Iceland and Serbia might become members in the near future. Croatia is set to formally become the $28^{\text {th }}$ member state of the EU in July 2013.

${ }^{70}$ Charlemagne, "Game, Set and Match to Angela," The Economist(2010), http://www.economist.com/blogs/charlemagne/2010/10/euro-zone_governance. Due to the lack of unanimity about the issue (with the UK and the Czech Republic dissenting) the Treaty on Stability, Coordination and Governance in the Economic and Monetary Union-usually referred to simply as "Fiscal Compact" was signed in March 2012 as an intergovernmental agreement, entering into force in January 2013.

${ }_{71}$ Vivien A. Schmidt, "L'europe À La Carte ?," Telos(2008), http://www.teloseu.com/fr/article/l_europe_a_la_carte. The concept is not new, though Eurospeak it is usually denominated as "enhanced cooperation, established formally in the Amsterdam Treaty, but specified in its operational details in the Treaty of Nice, Article 43". See: "Enhanced Cooperation," Europa Website(2011), http://europa.eu/legislation_summaries/institutional_affairs/treaties/nice_treaty/nice_treat y_cooperations_en.htm. 
${ }^{72} \mathrm{~A}$ particular avenue does exists in the Lisbon Treaty, on Title IV, Articles 20, 82, 83, 86, and 87 of the Consolidated Version of the Treaty on European Union, and on Part VI, Title III, Articles 326-334 of the Consolidated Version of the Treaty on the Functioning of the European Union, among others. The possibility of differentiated collaboration is termed there "enhanced cooperation". European Commission, "Consolidated Versions of the Treaty on European Union and the Treaty on the Functioning of the European Union, and Charter of Fundamental Rights of the European Union," Official Journal of the European Union(2010), http://eur-

lex.europa.eu/LexUriServ/LexUriServ.do?uri=OJ:C:2010:083:FULL:EN:PDF.

${ }^{73} \mathrm{~A}$ creative idea in this vein, for the field of labour policy, proposes making citizenship attainable for migrant workers and so benefit host societies with their improved allegiance. Giovanni Di Lieto, "Allegiance and Identity in a Globalised World," in Connecting International Law with Public Law, ed. Nolan Rubenstein, Jenkins (Cambridge: Cambridge University Press, 2010). Proposals of differentiated cooperation have grown as the eurozone crisis deepens, see for instance: K. Dyson and A. Sepos, Which Europe?: The Politics of Differentiated Integration (Palgrave Macmillan, 2010).

${ }^{74}$ The idea of a stateless polity requires an appropriate awareness, and at the same time transcendence of the political categories that have come to us from the nineteenth century. See: Eva Lester, "Disenfranchising the Disenfranchised: The Foreclosure of Allegiance, the Fixing of a Faceless Identity and the Legacy of the Nineteenth Century Globalisation," in Allegiance and Identity in a Globalised World, ed. Nolan Rubenstein, Jenkins (Australian National University: Centre for International and Public Law, 2010), 13. See also footnotes 111 and 176.

${ }^{75}$ See: Jiménez Lobeira, "EU Analogical Identity - or the Ties That Link (without Binding)."

${ }^{76}$ Iain Begg, Joseph Weiler, and John Peterson, Integration in an Expanding European Union: Reassessing the Fundamentals (Oxford: Blackwell, 2003), 21.

${ }^{77}$ Weiler's remarks were advanced during the debate about the creation of a Constitution for Europe (2003).

${ }^{78}$ Begg, Weiler, and Peterson, Integration in an Expanding European Union : Reassessing the Fundamentals, 22. The main reason why Weiler objected to the creation of a European constitution was that this Grundnorm of European constitutionalism and essential feature of the European polity, indeed, could be lost.

${ }^{79}$ For more on the concept of analogy as I am using it see: Mauricio Beuchot, En EI Camino De La Hermenéutica Analógica, Aletheia (Salamanca: San Esteban, 2005), 19-24., and John Deely, "The Absence of Analogy," The Review of Metaphysics 55, no. 3 (2002)..

${ }^{80}$ True, solidarity was and is stronger between those who see themselves as belonging to the same people (usually a nation, which may or may not coincide with a state). But that does not mean that some solidarity could and cannot exist in a wider community of peoples, perhaps not seeing each other as "political siblings" but at least as "political cousins".

${ }^{81}$ Habermas, Ratzinger and Bhutto are but three examples. See: Ratzinger, Dialectics of Secularization., Pope Benedict, Without Roots : The West, Relativism, Christianity, Islam / Joseph Ratzinger Now Pope Benedict Xvi, Marcello Pera ; Foreword by George Weigel ; Translated by Michael F. Moore, ed. Marcello Pera, George Weigel, and Michael F. Moore (New York, N.Y. :: Basic Books, 2006)., Joseph Ratzinger, Truth and Tolerance - Christian Belief and the World Religions, trans. Henry Taylor (San Francisco: Ignatius, 2004)., and - - C Christianity and the Crisis of Cultures, trans. Brian McNeil, Hardback ed. (San Francisco: Ignatius, 2006). Ratzinger, Dialectics of Secularization., J. Habermas, "Equal Treatment of Cultures and the Limits of Postmodern Liberalism*," Journal of Political Philosophy 13, no. 1 (2005).,_- - "Religion in the Public Sphere," European Journal of Philosophy 14, no. 1 (2006); Eduardo Mendieta, "Rethinking Secularism: A Postsecular World Society?: An Interview with Jürgen Habermas," in The Immanent Frame Secularism, religion and the public sphere, ed. Jonathan VanAntwerpen, SSRC (2010). and Habermas, An Awareness of What Is Missing - Faith and Reason in a Post-Secular Age. Benazir Bhutto, Reconciliation : Islam, Democracy, and the West, 1st ed. (New York: 
Harper, 2008), 233-318.

${ }_{22}$ Theodore Gabriel, Christian Citizens in an Islamic State : The Pakistan Experience /

Theodore Gabriel (Aldershot ; Burlington, Vt. :: Ashgate, 2007)., J. rgen S. Nielsen,

Yearbook of Muslims in Europe (Leiden; Boston: Brill, 2009).

${ }_{83}$ See about their latest initiative: Jeff Israely, "Vatican Launches Catholic-Islamic Dialogue,"

TIME no. 4 Nov 2008 (2008), http://www.time.com/time/printout/0,8816,1856185,00.html.

${ }^{84}$ Davie, "Religion in Europe in the 21 Century: The Factors to Take into Account," 288-90..

${ }^{85}$ Ibid.: 294.

${ }^{86}$ Recent examples in secularist regimes are the persecution of religion ("Cristero War"

in Mexico 1926-1929): J. Meyer, La Cristiada: The Mexican Government's Persecution of the Church (Square One Pub, 2009). Also in the Soviet Union: P. Froese, The Plot to Kill God: Findings from the Soviet Experiment in Secularization (University of California Press, 2008). China could be mentioned too. In Christian regimes, XVI and XVII century Europe provides abundant examples. For persecution of other religions in Islamic regimes, apart from Iran, see for instance: Gabriel, Christian Citizens in an Islamic State : The Pakistan Experience / Theodore Gabriel.

${ }^{87}$ Which I understand as the place where the political culture if found, formed and transformed. See a more comprehensive definition in: Taylor, A Secular Age, 185-86.

${ }^{88}$ Just to mention a few: Joseph Ratzinger (now Benedict XVI) and Charles Taylor (Christians), Joseph Weiler and Rabbi David Rosen (Jewish), Ayatollah Seyed Mostafa Mohaghegh Ahmadabadi and Muhammad al-Sammak (Muslims). See as an example Weiler's analysis of a recent and emblematic case (Lautsi): JHHW, "Editorial," European Journal of International Law 21, no. 1 (2010).. For an overall and synthetic view on the case, see: Lorenzo Zucca, "A Comment on Lautsi," EJIL: Talk!, no. 19 Mar 2011 (2011), http://www.ejiltalk.org/a-comment-on-lautsi/.

${ }^{89}$ Habermas's, for two reasons: first, he has accurately described the problem of a neutral public sphere, realising that "secular" is not always a synonym of "neutral" (i.e. when it becomes "secularist"); secondly, his point of departure is the dominant political cultural view in Europe today (secularism), but he is a moderate; because of that, finally, he has been able to engage in very productive discussions with moderate believers.

${ }^{90}$ Habermas, "Equal Treatment of Cultures and the Limits of Postmodern Liberalism*," 23. For a wonderful and thorough study on the public sphere, which has become a point of reference, see also: J. Habermas, The Structural Transformation of the Public Sphere: An Inquiry into a Category of Bourgeois Society (MIT Press, 1991).

${ }^{91}$ Habermas, "Religion in the Public Sphere," 15.

${ }_{92}$ Ibid.: 15-16.

${ }^{93}$ Ratzinger, Dialectics of Secularization, 77-78.

${ }^{94}$ Graeme T Lloyd et al., "Dinosaurs and the Cretaceous Terrestrial Revolution,"

Proceedings of the Royal Society B: Biological Sciences 275, no. 1650 (2008). 